Primljeno: 15. 4. 2012.

Stručni rad

UDK: $37.014 .523: 376$

\title{
ACHIEVING THE OBJECTIVES AND TASKS OF RELIGIOUS TEACHING IN SCHOOLS INCLUSIVE
}

\author{
Zivorad M. Milenovic, PhD \\ Teacher Training Faculty, Leposavic \\ E-mail: zivorad.milenovic @ pr.ac.rs
}

\section{SUMMARY}

Inclusive schools involves constantly involves each student barriers to learning and participation (ie, individuals with mild developmental disabilities, talented and gifted) and all other students in all aspects of educational activities in teaching, and extracurricular, social and cultural helpful public, according to their individual potentials (cognitive, conative, social and moral, affective and psychomotor) and the maximum of the expected learning outcomes, creating and teaching. Inclusion in education is defined as the process of learning and education for children with special educational needs, in which all children have equal opportunities to develop their physical, spiritual, emotional, social and other skills. The introduction of religious education in schools, on the one hand is a flagrant violation of the privacy regulation religious beliefs and freedom of religion. On the other, terminating the religious equality. That is because, as the right to religious education in some countries, recognized only by members of the dominant churches, as for other minority religious education and does not perform because of the small number of children that could attend. In Serbia, this right was recognized except the Serbian Orthodox Church and the Catholic Church, Islamic and Jewish communities, Slovak-Evangelical, Reformed-Christian and the Evangelical Christian church. It is not however recognized and other minority communities and their churches. Therefore, it was discrimination against minority religious communities, whose members are unable to attend classes that suit them in today's elementary and high school, opting to attend classes in civic education. This problem is present in other countries in the region. Present in Europe. In addition, religious education conducted mainly clergy who do not have the necessary professional and technical knowledge, pedagogical-psychological, methodological and other competencies for teaching in schools. Goals and objectives of religious education in terms of inclusive school and therefore can not be achieved, at 
least not completely. To achieve this, it would be nice that instead of religious education in Schools introduce the history of religion. This would be clearly studied the basic principles of each religion. Classes would be performed by teachers who are competent to do so. And priests in the instruction was occasionally involved in a religious capacity as assistants. This would avoid that this study leaves the framework of religion and religiosity, which go into the teaching of religion in conditions and under circumstances in which they performed in schools quite possible. A possible would seem that religious education can attend all children, regardless of background, race or religion. These issues will be discussed in this paper.

Keywords: inclusion, inclusive schools, inclusive education, religious education, religion, the aims of religious education, the tasks of religious education

\section{INTRODUCTION}

The Education Reform of the social and pedagogical process. It $s$ the one hand, fundamental policy changes and education position, the position of students and teachers in education and organization of the education system and its contents. On the other hand, the education reform requires a new school organization, use of modern and proven methods, application of new teaching technologies, the introduction of optional subjects, keeping above average, and giving more importance to students who have barriers to development, learning and participation. In the last twenty years in the geographic space of the former Yugoslavia, there have been numerous changes. They expressed the need to review certain aspects of education. One is the relationship between religion and education. That is a different sense, and especially how to incorporate religion in education. This is because the relationship between education and religion caused by the established hierarchy of values in society. But the policy of support for these values that will guide the young to the material only or, perhaps, spiritual values, or to find a reasonable measure of them.

In terms of religious education in public schools, more mature belief that there is no educational system can afford to ignore the role of religion and belief in the history and culture. Ignorance in this area can lead to negative stereotypes. And in its extreme forms can lead to hatred, conflict and violence. Recent history clearly demonstrates. Everything is widespread consensus that the knowledge, religion and belief is an important part of quality education that can enhance the democratic society and mutual respect. But to strengthen support religious freedom and promote understanding of social diversity. Or put another way, that dialogue and tolerance were established between religious communities and believers, it is necessary to bring up and educate believers and for dialogue and tolerance, except for the knowledge of the doctrine of their own religion.

It is noticeable that the school through its activity is directed at the shortcomings and weaknesses in their work, especially when it comes to students with developmental disabilities. In the past, and therefore came to the separation and paralyze the inclusive 
education. The new system takes into account the special education learning needs of students. The company sets the task of implementing inclusive school education, to ensure systematic knowledge acquired through active learning of each student in relation to his ability. Inclusive education can be achieved in an inclusive school. In this paper, the theoretical level, to discuss the possibilities and limitations of achieving the goals and objectives of religious education in an inclusive school.

\section{TERM OF RELIGION AND RELIGIOUS EDUCATION FACILITIES}

Religion is a subject of many sciences and disciplines. For its importance, and many authors suggest the need to deal with the study of religion and religious education (Kuburic, 2000; Mandaric, 2000; Vrcan, 2001; Jerolimov Marinovic, 2002, Mihailovic, 2004). Sociologists define religion as "[...] differentiated form of social consciousness in a fantastic way to explain the relationship between people and their relationships to nature and unreal supernatural forces that rule the world" (Ivkovic, 1998, p. 174). The philosophical sources, religion is often equated with religious experience, which includes the "[...] every experience in which the content is present and something divine or transcendetno" (Blackburn, 1999, p. 371). Kiril Vasilj, connecting religion with the natural and social sciences, the term religion means "[...] living metaphysical truth that God exists as the personal creator of man and all of the physical world [...]" (1997, p. 34). In contrast, Cedomir Cupic said that as the conditions for successful inter-religious dialogue identified "[...] equality (the acceptance of other religions as equals), vigilance (especially the members indicate their religion on others need to listen to and support the good intentions), politeness (avoid anything that could be interpreted as insulting, derogatory and demeaning to the other) and select arguments in an interview that closer contacts and mutual support "(2008, p. 83-84). These and other definitions indicate that religious education is an integral part of religion. Involves the study of the four sub-themes. They are: (1) disadvantages of religious education, (2) the need for religious education, (3) benefit of religious education and (4) proposals content of religious education.

The disadvantages of religious education. In recent years the countries of former Yugoslavia is at once a sharp increase in the number of believers. They are however scarce and / or without religious education. Among them, the ignorance of government and large gaps in knowledge about each other. These gaps are best filled with indifference and often misconceptions, and prejudices. That is why created an identity crisis as a model for interpretation of the world to an end, and the new is not created. In this regard konstantuje that everyone must be familiar with the history of the development of religious traditions. But culture and religion of all who live in the geographic space of the former Yugoslavia.

The need for religious education. Diagnosis of occurrence of intolerance is that it is in many cases the result of faulty or inadequate education. It is therefore necessary awareness, tolerance and respect in every man, be he a believer or not. This can be achieved only through education, first within his own religious doctrine. It should be 
noted that no religious doctrine (at least so in their programs), does not call for violence against others. It is necessary, therefore, spread tolerance through education and learning about other religions. To put it another way means that the basis of every religion in the knowledge and appreciation of other religions. All this suggests that only through education can get an answer to the question, again to accept religion as a part of society and the environment?

Use of religious education. In the process of reconciliation in post-conflict societies, education is most important. It is reflected in the determination of the cause, but also pave the way toward future intercultural and multicultural society. There is a need to instead of creating conflict, people learn to live alongside people of other religions and other worldviews. Because the children in the religious education should be accustomed to diversity as a natural human characteristic. That's why getting to know children and young people with the faith they belong to other faiths and the real beginning to be developed later in the dialogue of opposing parties. The school system was introduced as a religious teaching and / or religious subject. It is intended to be a form of opportunities to educate young people and understand their faith and others. At the same time it emphasizes the need for discussion on the common system of values and value system of European integration as a key factor. This is because religious syncretism - interactions of various religious influences better suited the needs of today's societies.

Suggestions content of religious education. Among the proposals for the content of religious education, some practical nature. As a call: Let's invest in organizing cultural events, visit the temples of different religions, student exchange. In addition to the medieval Orthodox monasteries and churches to be visited other religious communities, synagogues and mosques. It is important to teach children the heritage of all cultures prices. Would be interesting and the students present their religious tradition and contribute to understanding the complexity of various world religions. On a general level it is stated that it is necessary to introduce the program through which school children will be able to learn about different religions and customs. On religion courses should be organized study of the great religious systems: Find someone else's name known in your letter and give the hand to your neighbor. Notes and the openness to dialogue and cooperation with others just seem quintessence of religious teachings. And once you get to know their students and the religious teachings of others, can access the search of common ground in order to encourage understanding and cooperation. Because it is the duty of a democratic society to make available knowledge about the religious, ethnic and social organization of other minority communities.

\section{ORTHODOX EDUCATION CATECHISM IN THE ELEMENTARY GRADES IN SERBIA}

In the first grade of primary school teaching is studied eight subjects. They are: (1) introduction, (2) God is a community of persons of Father, Son and Holy Spirit, (3) The Church is a community of all people and all nature with God through Christ, (4) 
Jesus Christ is the mediator between God and created nature , (5) God created the world out of love with the Son and Spirit, (6) Church is a community of all people and all nature with God through Christ, (7) man is an icon of God (the man has the capacity to love doing something that exists, similarly as it does God because God created all love) and (8) Orthodox iconography shows the world and man in union with God (PS "Cele Kula", 2010). According to the objectives and tasks of religious education in the first grade of elementary school students should: (a) notice that the ratio of free love for someone and something that a more concrete, (b) notice that every human being to other people and gives them a unique nature and value of existence (c) notice that the one he loved, and their existence depends, and (d) teach that man is an icon of God.

In second grade studied seven educational topics. They are: (1) introduction, (2) God is a community of persons of Father, Son and Holy Spirit, (3) The structure of the Liturgy - Church (4) Liturgy - discovering God, (5) The liturgy is the presence of Hirst and anticipation of the arrival of Christ, (6) the existence of nature is an expression of love of God and man and (7) God created the world to him is eternal community of love through man and man in this community is unique and eternal being. Objectives and tasks of religious education in the second grade of primary school is to be the awareness that God is a communion of persons and to discovering the world through the liturgical community. In addition, students should: (a) know that the liturgy is not an ordinary event, (b) notice that the Liturgy, God appears as a community of persons of Father, Son and Holy Spirit, (c) present the structure of the Liturgy, (d) to distinguish the actions of the liturgy and (e) Note that Jesus Christ is present in the liturgy.

In the third grade curriculum is taught six subjects. They are: (1) introduction, (2) God has created a unique world and as many specific types of nowhere, (3) the consequences of being created by the nature of its existence, (4) the creation of man at the end of all creation in the image and will God, (5) The Eucharist as a world within itself, and (6) the creation of the world and man in Orthodox iconography. According to the objectives and tasks of religious education in third grade, students should: (a) to note that people like the person did not exist before they were born, (b) realize that God created the world out of love for eternity, (c) noted that God created the world as a set of specific species, (d) to know that God created man as a person, (e) to tell the difference between nature and personality in humans and (f) notice that the structure of the created world is reflected in the liturgy.

In fourth grade studied eight teaching topics. They are: (1) introduction, (2) the goal for which God created the world, (3) The Church is a concrete liturgical community, (4) The liturgy is a community of many people and nature and with God the Father through Christ a man, (5) structure of the liturgy, (6) The Church as an icon of the age, (7) the refusal of the first man Adam was created to unite with God and nature (8) Church in the Christian liturgy. According to the objectives and tasks of religious education in fourth grade, students should gain knowledge about the existence of the world has its own goal. In addition, students should: (a) build a general awareness that God is a man with the world through Christ, (b) notice that the corporate personality of Christ, (c) notice that the Church no one can exist by itself without all the community, (d) to 
acquire the concept of being in the community, and (e) realize that all sin is the source of egoism.

The outlined goals and objectives of religious education from first to fourth grade, there is an evident conflict between the tasks and goals with a religious education on the other hand, as well as between the goals of religious education on the one hand and development capabilities and features junior school with On the other hand, because the goals and objectives of religious education designed to abstract learning. As an example: to children through believing in God they learn to trust people. Younger school children learn in real circumstances, and this is their religious teachings nerazmljivo and foreign. So i do not understand what they are learning. And have a resistance to religious education.

\section{INDIVIDUALISATION AIM OF EDUCATION IN INCLUSIVE SCHOOL}

There are many definitions of inclusive education. According to Mile Ilic, inclusive school "[...] includes the constant is inclusive of students with barriers to learning and participation (ie, individuals with mild developmental disabilities, and above average) and all other students in all aspects of educational activities, educational, extracurricular, social -beneficial cultural and public, according to their individual resources (cognitive, conative, social, moral, affective and psychomotor) and the maximum expected outcomes of learning, creating and teaching" (2010, p. 17). A implies the involvement of numerous actors in an inclusive process: students, teachers, educators, school management, non-teaching staff of primary schools, parents and local community representatives (Milenović, 2009, p. 593). In order for inclusive education in an inclusive school provided educational effects, it is necessary to mention that the subjects are included in the training, testing and planning the development of inclusive schools, but also the realization of the goals of education in an inclusive school.

In theory, the goal of education is defined as the formation of all-round personality. Under all-round developed personality means a person with a remarkable physical, intellectual, moral, technical and aesthetic qualities (Krulj et al., 2003, p. 76). The degree of versatility as to achieve the goal of education is largely dependent on the individual man as a natural being and its working-creative activity. Comprehensively developed personality is considered to be the individual who is equally developed in all properties and fields. However, she developed a personality who was able to develop their potential (disposition) and to achieve what they could achieve. Developed personality is still the occupant of the maximum developed features that have the best disposition. Educational ideal of an inclusive school and / or the ultimate aim of education is, therefore, multiple, or all-round development of personality, according to the capacity of the individual, making the process of developing comprehensive individualized personality.

The textbooks and literature on inclusive schools and teaching, the general aim of education is not precisely defined. This is because it stems from the definition of the essence and character of inclusive education. Inclusive education is considered as an in- 
tentional education, as well as self-education and "[...] shall mean the individual and society as a process of teaching and learning in which there is a relatively enduring and progressive changes in individual circumstances simedonijske support and social inclusion" (Suzic, 2008, page. 11). Starting from a definition of inclusive schools, inclusive education and inclusive education, the educational ideal, or copulate, and the ultimate goal is to multiply and develop harmonious personalities, according to the capacity of the individual.

As shown, the process of developing a harmonious personality in an inclusive school is individualized. Individualization aim of education in an inclusive school involves the goal of education for each student or group of pupils with special educational needs. For this reason, it is not easy to determine the number of individualized education goals in an inclusive school. Except for the above average, there are individual goals of education for students with barriers to learning and participation. The group of students with barriers to learning and participation include students with vision impairments, hearing, speech, difficulties in reading, writing and teaching elementary mathematics content, students with physical disabilities and health disorders, mentally developed enough students, students with behavioral problems and students with specific problems of psychological development.

Working with pupils with special educational needs in inclusive school is individualized. Therefore we are talking about the individualization of education objectives in an inclusive school. Based on these factors, the goal of education in an inclusive school is the formation and harmonic development of student personality and his human, physical, intellectual, moral, aesthetic, cultural and technical labor resources and values, according to their special educational needs, individual potential, interests and expected outcomes of learning, creating and learning to optimal development.

\section{SOME SHORTCOMINGS RELIGIOUS TEACHING}

Disadvantages of religious education in primary schools, especially in elementary grades are numerous. At the same time, numerous studies have shown (Larsen, 2000, p. 97; Gearson, 2003; p. 123; Thompson, 2008, p 32). That in younger school age and no true religion. Religious Education "[...] is not in accordance with their general intellectual development and abilities, which are characteristic of this age, and they are concrete operations" (Alberts, 2008, p. 108). But that said Vlatko Previsic, the sociodemographic characteristics of students and the social distance towards national and religious grupana (1996). In contrast to the results of these studies, religious education includes practical actions (participation in religious ceremonies), and abstract thinking that children generally develop only in the 14th and 15th, and early in the 12th year of life.

All this does not mean that children should be completely deprived of opportunities to familiarize themselves with the general contents of faith and religion. On the contrary, "[...] young school age children through appropriate activities at the school learn about the meaning and significance of religious holidays celebrated by schools" 
(Freathy and Parker, 2010, p. 239). At the same time "[...] to choose the content of religious character, and not put any other religious and ritual" (Erricker, 2010, p. 53). This would avoid the undesirable ideologically in this direction. Accordingly, the primary school should not be organized or denominational or non-confessional activities for children. In the course of proving the claims presented in this paper is the thesis that the nine states Miomir Ivkovic (2009).

1. What are the criteria to distinguish religious education and religious upbringing? Simply phrased, in religious education includes knowledge of religious phenomena, which are reached and the scientific method that can be checked in the same way, and determined to learn. To the knowledge of the contents in which a man must not believe, nor are they incorporated into their behavior. Religious (religious) education means just a belief, and behavior evaluation in accordance with certain orientations. Because religious culture is not and can not be the goal of education, nor can have their functions in the school. Functions of religious culture are realized in the church and leave it to be.

2. Religious (religious) and religious education of children in elementary school? What to choose? In searching for the answer to this question: what and how to work in primary schools (especially with younger school age children), should use the results of psychology. Modern, however, studies in psychology, especially in developmental psychology, in simple terms, show that in children under 13, and the earliest to 11 age has no religion. This is in line with their general intellectual development and abilities that are characteristic of this age, which are specific operations.

3. In this period the child can apply logical operations when solving problems involving concrete objects and events. But, at this age a child can not be resolved: (a) problems that are purely verbal, and (b) problems that require complex thinking operations.

4. At this age your child has a real show, and there is no abstract. Religious representations are abstract.

5. The first performances of the religious phenomenon of the real nature and the only children affected by their participation in the ceremonies. Elementary school, certainly, should not be practiced such rites. Religious rituals are the subject of church and church activities. And that should remain in today's society.

6. Children in elementary school should not bother studying religious phenomena. The real danger of such attempts exists. This is because in today's society worrying randomness in the area of education policy, even more considering the only one that should be expected, caused by a long drought in the field of religious knowledge, but also fashion and real indifference today's society.

7. Is it still possible to do something and do it in elementary school? It is possible and should be called children through appropriate activities meet the meaning and significance of religious holidays, which marks the primary school (for example St. Sava in Orthodoxy, and similar holidays in Islam, Catholicism and other religious communities). In selecting the content of a religious nature, not religious, and no accompanying ritual. This would avoid the undesirable ideologically in this direction.

8. Mandatory religious education, religious education, catechism in primary school 
would be as decidedly inappropriate - and how to impose any ideological view of the world, and theistic, and atheistic, and materialistic, and idealistic, and the like.

9. Following the above, the primary school (at least not at early school age) should not be organized or denominational or non-confessional activities for children.

\section{ACHIEVING THE OBJECTIVES AND TASKS OF RELIGIOUS TEACHING IN SCHOOLS INCLUSIVE}

Based on previously presented definitions and discussions of inclusive education, goals and tasks of religious education under conditions and circumstances that exist in today's primary schools can not be fully realized. And / or not all students equally. This is because the right to religious education in some countries, recognizes only the dominant members of churches, as for other minority religious education and not performed due to the small number of children who would attend. In Serbia, this right is recognized but the Serbian Orthodox and Catholic churches, Islamic and Jewish community, the Slovak-Evangelical, Reformist-Christian and Evangelical Christian Church. But it is not recognized and other minority communities and their churches. Therefore we are talking about discrimination against minority religious communities, whose members are unable to attend religious education that suits them in today's elementary and high school, opting for the attendance of civic education. This problem is also present in other countries in the region. It is present in Europe. In addition, most classes are taught by religious clerics who do not have the necessary professional and technical knowledge, pedagogical and psychological, methodological and other competencies for teaching in schools. All this is contrary to the principles of inclusive education in an inclusive school, which involves the inclusion of all students regardless of their psychological and physical development, ethical, racial, religious, gender, linguistic or any other affiliation. Because there is no religious instruction and the educational effectiveness of the measure in which to expect. And its performance is reduced to a formality and connivance religious communities.

O make the objectives and tasks of religious education in an inclusive school is fully realized, it would not be coming to discrimination against members of minority communities and to prevent religious instruction to leave the framework of religion and religiosity in the yarn, it is necessary to organize religious instruction in a way that will to remove its main drawbacks.

1. Starting from the theoretical (scientific), the general social and practical significance, but also the need of studying religion as a significant social category, instead of the current school religious education, to introduce the history religion of the subject of, which would be a compulsory subject, instead of electoral character of religious education.

2. Educational facilities should choose a team of professionals (teachers, psychologists, didactics, methodologists, art historians and scholars in the field of religion). They need to be adapted to the needs and abilities of students. First of all developmen- 
tal age of students and their intellectual abilities and psychophysiological functions (perception, thinking, understanding). But to be based on learning opportunities in real, rather than irrational circumstances and the eschatological and religious topics.

3. Introduction of all children, regardless of membership in a particular religious community, the foundations and principles of each religion. Especially highlight the contribution of religion to the development of society. To achieve this, it is necessary to take all the children in churches, mosques, synagogues, monasteries, convents and other religious buildings and introduce them to their purpose and importance of having certain religious communities and society as a whole. This would be apart from the material, made the formal and functional educational tasks of religious education. Or would be eliminated and stereotypes and fears that children sometimes have to other religious sites.

4. To study the contents of which are present in all religions, and contributing to the moral vaspitanjeu children (forgiveness, belief, respect, repentance, sacrifice, perseverance, loyalty, honesty friendship, fellowship, courtesy, obedience, humility, etc.).

5. history of religions in an inclusive school organizovovati within four main phases. They are: (1) diagnostic, (2) preparation, (3) operational and (4) the evaluation phase. But through the eight stages: (1) identification of developmental and educational potential and needs, (2) the planning history of religion in inclusive teaching, (3) preparation classes, (4) introduce students to the study of the history of religion, (5) processing of new contents or program content from the history of religion, (6) repeating new material, (7) and exercise (8) evaluation.

6. Starting from the characteristics of religious education classes and one in an inclusive school with the other hand, as well as special educational needs of students in inclusive continues, it is necessary to perform the teaching of history of religion in the principles and methods, and models of work which have not been applied in traditional teaching. In addition to didactic-methodical models inclusive of traditional teaching, the teaching of history of religion should be performed by the didactic-methodical innovative models of inclusive education. As those proposed by Mile Ilic (2010, p. 332-413). They are: (a) didactic-methodical models inclusive of individual courses (inclusive individualized instruction using instructional sheets, inclusive teaching different levels of complexity, inclusive of students work on tasks of varying difficulty, inclusive individually planned teaching, micro teaching inclusive, inclusive-branched programmed instruction model and inclusive computer classes), (b) didactic-methodical models of inclusive interactive teaching (inclusive interactive teaching different levels of complexity, students in inclusive work group level, an inclusive group work, and tandem inclusive education, inclusive work of students in the puzzle, the work of students in inclusive the educational workshop, inclusive of responsible teaching interactive exemplary inclusive education and inclusive.

7. The history of religion should be carried out by competent teachers who have to do professionally trained and have the pedagogical-psychological, methodological and other competencies for teaching. In this connection, the teachers' colleges to open the directions of the two religious teachers Niva: (1) basic academic studies - Bečalor 
and (2) graduate studies - Master.

8. In exceptional cases, religion may also teach students who have completed the Theological Faculty (Orthodox or Catholic), Faculty of Islamic Theology Faculty or other religious communities in four years. But as long to complete one-year additional pedagogical-psychological and didactic-methodical training to acquire the necessary competencies for teaching. On the importance and need for additional psychological and pedagogical-didactic educational methods of indicating a number of authors (mainly from Russia and other states with geographic space of the former USSR, but also from the European Union), who studied the effectiveness of teaching students nenastavničkih School (Шиян, 1996; Гаргай, 2000; Иноземцева, 2000; Phillips, 2000; Vasconcellos, 2004; Kapranova, 2004). It is in their research points to the lack of teaching skills among these teachers.

9. The teaching of history of religion, and in accordance with the principles of inclusive teaching assistants constantly engage religious (priests, monks, priests, rabbis, monks, nuns, abbots, nuns etc.), that their presence in the classroom contributed to the realization of the objectives and tasks of religious education in inclusive education. Or contribute to achieving the goals and objectives of teaching, and the expected outcomes of teaching, learning, creating and learning and achieve optimum development of each student with special educational needs in inclusive education.

\section{CONCLUSION}

This paper discussed the theoretical level of achievement of the objectives and tasks of religious education in an inclusive school. Starting from the theoretical (scientific), social and practical significance and purpose of studying religion in primary schools on one hand, and the specifics of working with children with special educational needs in inclusive teaching on the other hand, pointed to some shortcomings of religious education and the ways of their solution. It was observed that the younger school children and there is no true religion. That religious education is not in accordance with their general intellectual development and abilities, which are characteristic of the school, primarily under school age. Therefore, it might get the impression that religious education has caused more controversy, confusion and prejudice, than there are educational effectiveness in the classroom. It is often created resistance to religious education, in doubting its validity and necessity. But the demand to abolish religious education as a subject in primary schools. All this does not mean that religious education should be abolished in primary schools and children deprived of a fully able to familiarize themselves with the general contents of faith and religion. Instead, through appropriate activities at school to get to know them with meaning and significance of religious holidays and the basis of every religion, stressing its social importance and necessity. In selecting the contents of religious nature, not religious, and no accompanying ritual. At the end of the paper, presents some suggestions for the successful achievement of goals and objectives of religious education in an inclusive school. Or that in elementary school instead of religious 
education as an elective, taught history of religion as a compulsory subject. Classes instead of the priest and the teacher to superficially prepared for the courses and seminars, performed by a qualified religious teachers who would be educated in separate directions in teacher education, pedagogical and philosophical faculties. This would avoid the undesirable ideologically in this direction. A would prevent the religious teaching that went beyond the religious and the religious cross, as the conditions and circumstances that religious education was carried out up to now quite certain.

\section{BIBLIOGRAPHY}

1. Alberts, W. (2008). Integrative Religious Education in Europe. Berlin: Walter de Gruyter GmbH \& Co.

2. Blekburn, S. (1999). Oksfordski filozofski rečnik. Novi Sad: Svetovi.

3. Čupić, Č. (2008). Zašto su potrebni interreligijski dijalog i tolerancija. U: Č. Čupić (ured.) (2009). Zbornik radova „Religije Srbije, mreža dijaloga i saradnje“ (str. 8493). Beograd: BOŠ.

4. Erricker, C. (2010). Religious Education: A Conceptual and Interdisciplinery Approach for secondary level. New York: Routledge.

5. Freathy, R. and Parker, S. (2010). The Necessity of Historical inquiry in Educational Research: The Case of Religious Education, British Journal of Religious Education, Vol 32, No.3 (p. 229-243).

6. Гаргай, В. (2000). Повышение квалификации учителей на Западе: рефлексивная модель обучения. Педагогика, Но. 2 (стр. 72-81).

7. Gearson, L. (2003). Citizenship trough secondary religious education. New York: Routledge.

8. Ilić, M. (2010). Inkluzivna nastava. Istočno Sarajevo: Filozofski fakultet Univerziteta u Istočnom Sarajevu.

9. Иноземцева, В. (2000). Подготовка педагогических кадров в вузах России. Педагогика, Но. 6 (стр. 57-64).

10. Ivković, M. (2009). Ni religiozno/versko, ni religijsko vaspitanje dece u predškolskoj ustanovi. U: M. Projović (ured.) (2009). Naše stvaranje - Zbornik radova sa četvrtog simpozijuma „Vaspitač u 21. veku“, održanog 28. i 29.03.2008. godine u Sokobanji (str. 27-28). Aleksinac: Visoka škola za vaspitače strukovnih studija u Aleksincu.

11. Ivković, R. (1998). Sociološki leksikon. Prizren: Prizrenske novine.

12. Kapranova, V. (2004). Сравнительная педагогика. Минск: Новое знание.

13. Krulj, R., Kačapor, S. i Kulić, R. (2003). Pedagogija. Beograd: Svet knjige.

14. Kuburić, Z. (2000). Vera i sloboda, Verske zajednice u Jugoslaviji. Novi Sad: CEIR.

15. Larsen, J. (2000). Religious Education and the Brain. New Jersey: Mahwah.

16. Mandarić, V. (2000). Religiozni identitet zagrebačkih adolescenata. Zagreb: Institut društvenih znanosti „Ivo Pilar“.

17. Marinović Jerolimov, D. (2002). Religious Distance in Croatia, In: M. Christian (ed.) (2002). „Images of the Religious Other“ (p. 201-217). Novi Sad: CEIR. 
18. Mihailović, S. (2004). Mladi zagubljeni u tranziciji. Beograd: Centar za proučavanje alternativa; Mršević, Z. Religijsko obrazovanje i proces „Toledo“. Religija i tolerancija, Vol. 7, br. 12 (str. 261-274).

19. Milenović, Ž. (2009). Značaj i potreba podsticanja i razvijanja inkluzije u obrazovanju. U: Branković, D. (ured.) (2009). Naučna i duhovna utemeljenost društvenih reformi - Zbornik radova sa desetih Banjalučkih novembarskih susreta održanih 27-28.11.2009. godine u Banjaluci (str. 591-602). Banjaluka: Filozofski fakultet Univerziteta u Banjaluci.

20. Phillips, D. (Ed.) (2000). The Education Systems of the United Kingdom. Oxford: Symposium Books.

21. Previšić, V. (1996). Sociodemografske karakteristike srednjoškolaca i socijalna distanca prema nacionalnim i religijskim skupinama, Društvena istraživanja, br. 5-6 (str. 859-874).

22. Suzić, N. (2008). Uvod u inkluziju. Banjaluka: HBS.

23. OŠ “Ćele Kula” (2010). Nastavni plan i program za školsku 2010/11. godinu. Niš: OŠ „Ćele Kula“.

24. Thompson, P. (2008). Whatever Happened to Religious Education. Cambridge: The Lutterworth Press.

25. Шиян, О. (1996). Послеуниверситетский тренинг учителей в США: новые ориентиры. Педагогика, Но. 1 (стр. 104-108).

26. Vasconcellos, M. (2004). Le système éducatif. Paris: La Decouverte.

27. Vasilj, K. (1997). Religija: prirodne i društvene znanosti. Mostar: Ziral.

28. Vrcan, S. (2001). Vjera u vrtlozima tranzicije. Split: Dalmatinska akcija. 